\title{
Calcium, strontium and osteogenesis
}

By J. F. Loutit, M.R.C. Radiobiological Research Unit, Harwell, Berks

The development and mineralization of the skeleton has always been a subject of general interest. Attention to the mineral aspect has naturally been focused on calcium, since its phosphates as apatites supply by far the greatest mass.

\section{Role of strontium}

Until the last decade $\mathrm{Sr}$, which is a chemical analogue of $\mathrm{Ca}$ and its nearest relation amongst the alkaline earths, was regarded merely as a minor element of little significance. A claim has, however, been made that $\mathrm{Sr}$ is an essential trace element necessary for bone strength (Rygh, I949). Since Sr is a contaminant in all sources of $\mathrm{Ca}$, mineral, vegetable (1000 p.p.m. or more) and to a less extent animal, natural deficiencies are not seen.

The present-day importance of Sr depends on the fact that two of its many radioactive isotopes are long-lived products of nuclear fission- ${ }^{89} \mathrm{Sr}$, half-life 50 days and ${ }^{90} \mathrm{Sr}$, half-life 28 years. These fission products, having been released through the testing of nuclear weapons, are now distributed universally, but variably with region, throughout the world. They occur as superficial contamination of or as inclusion in food. Major releases occur from the larger devices, first tested in $195^{2}$, and serially from 1954 .

In this country 'monitoring' for ${ }^{90} \mathrm{Sr}$ in human bone commenced in 1955 and has been carried out since by Bryant and his group at the Chemical Outstation of the Atomic Energy Research Establishment (reviewed by Bailey, Bryant \& Loutit, r960; Bryant \& Loutit, I96r). Bryant, Chamberlain, Spicer \& Webb (1958) initially undertook some pilot work on the contamination of food also, but since 1958 this work has been taken over by the Agricultural Research Council (Agricultural Research Council Radiobiological Laboratory, 1958 to I96I-2) (Table I).

Table I. Activity of ${ }^{90} \mathrm{Sr}$ in the national diet

\begin{tabular}{|c|c|c|c|}
\hline Year & & $\mathrm{pc}{ }^{90} \mathrm{Sr} / \mathrm{g} \mathrm{Ca}$ & $\begin{array}{c}\mathrm{pc}{ }^{90} \mathrm{Sr} / \mathrm{mg} \mathrm{Sr} \text {, calculated } \\
\text { from } \mathrm{Sr} / \mathrm{Ca}=1 \cdot 3 \mathrm{mg} / \mathrm{g} \\
\text { in national } \text { diet }^{(1)}\end{array}$ \\
\hline I 954 & & ?2 (2) & ? I.5 \\
\hline I955 & & $P_{4} \quad$ (2) & $? 3.1$ \\
\hline 1956 & & $?_{5} \quad$ (2) & $? 3.9$ \\
\hline 1957 & & $5 \cdot 5^{(3)}$ & $4 \cdot 2$ \\
\hline I958 & & $5^{\circ} 9^{(1)}$ & 4.5 \\
\hline 1959 & & $9^{\circ} 0^{(4)}$ & $6 \cdot 9$ \\
\hline 1960 & & $6 \cdot 4^{(5)}$ & $4 \cdot 9$ \\
\hline I 96 I & & $6 \cdot 2^{(6)}$ & 4.8 \\
\hline & (1) & \multirow{6}{*}{\multicolumn{2}{|c|}{$\begin{array}{l}\text { ARCRL I. } \\
\text { Estimates (Bryant \& Loutit, 1961). } \\
\text { Bryant et al. (r958). } \\
\text { ARCRL 3. } \\
\text { ARCRL 5. } \\
\text { ARCRL } 8 \text {. }\end{array}$}} \\
\hline & (2) & & \\
\hline & (3) & & \\
\hline & (4) & & \\
\hline & (B) & & \\
\hline & (8) & & \\
\hline
\end{tabular}


Thus we have now accumulated a body of information about levels of ${ }^{90} \mathrm{Sr}$ in the national diet and in human bone. It is meet to consider what we can learn from it about the behaviour of $\mathrm{Ca}$ and $\mathrm{Sr}$ in the human body.

First, it should be noted that, though the measurements are made on known weights of animal or vegetable material, the results are usually expressed as so many $\mathrm{pc} / \mathrm{g} \mathrm{Ca}$, since the metabolic pathways of $\mathrm{Sr}$ mirror to a large extent those of $\mathrm{Ca}$. In plants there is little if any discrimination by the tissues between the movements of the two ions, but in animals certain processes do select in favour of $\mathrm{Ca}$. They probably all involve mechanisms of active transport. Thus in absorption into the body from the alimentary tract, reabsorption of the glomerular filtrate by the renal tubules, secretion of milk and transplacental passage there is discrimination in favour of Ca. Comar, Wasserman \& Nold ( $195^{6}$ ) have coined the term 'observed ratio' (OR), the simple relation, $\mathrm{Sr} / \mathrm{Ca}$ sample $\div \mathrm{Sr} / \mathrm{Ca}$ precursor, as an expression of the overall discrimination attributable to a number of separate metabolic factors. It should be considered only when conditions of equilibrium have been attained.

\section{The newborn}

We can see evidence of discrimination in transplacental passage from assays of the bones of the newborn (Bryant \& Loutit, I96I), and see it best with natural Sr. The mean value for 133 newborn infants (stillborn or a day old) was $207 \mu \mathrm{g} / \mathrm{g}$ Ca. For adult bone the value was $3 \mathrm{I} 9 \mu \mathrm{g} / \mathrm{g} \mathrm{Ca}$, which corresponds closely to the few values obtained for human plasma by my colleagues (G. E. Harrison, unpublished), namely $30-40 \mu \mathrm{g} / \mathrm{l}$. The OR can thus be written

$$
\frac{\mathrm{Sr} / \mathrm{Ca} \text { foetal bone }}{\mathrm{Sr} / \mathrm{Ca} \text { maternal plasma }}=\frac{207}{319} \simeq 0.6 \text {. }
$$

A similar OR can be derived from the data for ${ }^{90} \mathrm{Sr}$, but with less certainty because certain assumptions have to be included. Thus the bones of newborn in I959 had average values in $\mathrm{pc}^{90} \mathrm{Sr} / \mathrm{g} \mathrm{Ca}$ of $\mathrm{I}^{\mathrm{I}} \mathrm{I}_{3}$. Maternal plasma values are too low for measurement, but if a representative OR human plasma $\div$ human diet of 0.25 be taken, and diet in 1959 averaged $9 \mathrm{pc} / \mathrm{g} \mathrm{Ca}$, the OR

$$
\frac{\text { foetal bone }}{\text { maternal plasma }}=\frac{\mathrm{I} \cdot \mathrm{I} 3}{9 \times 0.25}=0.5 \text {. }
$$

\section{The infant}

We can now study our newborn infant with its $200 \mu \mathrm{g} \mathrm{Sr} / \mathrm{g} \mathrm{Ca}$ and its content of ${ }^{00} \mathrm{Sr}$ which varies with the year of birth (average $0.44,0.6 \mathrm{I}, 0.62, \mathrm{I} \cdot \mathrm{I}_{3}, 0.88$ and $0.72 \mathrm{pc} / \mathrm{g} \mathrm{Ca}$ in the 6 years I956-6r). Stable Sr alters little in the first 6 months but rises significantly to about $245 \mu \mathrm{g} / \mathrm{g} \mathrm{Ca}$ at I year of age. The corresponding ${ }^{90} \mathrm{Sr}$ figure again varies according to the year, the maximum value for the annual mean being in 1959 at $4.3 \mathrm{pc} / \mathrm{g} \mathrm{Ca}$.

Unhappily though good statistical data are available for the 'national diet', there is no reliable information about the 'infant diet'. Certainly there were many changes 
during this time. Breast feeding, which is universally recommended, appears to be practised less and for shorter periods than formerly (Newson \& Newson, 1962). Cow's milk, reconstituted from the dried state or fresh, appears to be the basis, with variable additions of cereals, fruit and vegetables. The values of ${ }^{90} \mathrm{Sr} / \mathrm{g}$ Ca for cow's milk, which are well documented in ARC reports, and for infant foods differ little from those for the contemporary 'national diet'. Thus for our purposes little error is induced by using the values of ${ }^{90} \mathrm{Sr} / \mathrm{g} \mathrm{Ca}$ of the 'national diet'. Stable $\mathrm{Sr}$, however, should be much less than in the 'national diet' since the basic foodstuff, milk, is low in Sr. We have estimated from Widdowson's (1947) survey of prewar children's diets that the content might be $500 \mu \mathrm{g} / \mathrm{g} \mathrm{Ca}$ at the age of I year (Bryant \& Loutit, r 96 I).

In the Ist year, growth is so rapid that it overshadows any turnover, which is probably considerable too. The skeletal mass of $\mathrm{Ca}$, according to Mitchell, Hamilton, Steggerda \& Bean ( 1945 ), increases from 28 to $100 \mathrm{~g}$ (Fig. I). Thus at least threequarters and possibly nearly the whole skeletal Ca have been formed from the recent diet, and it is fair to deduce an OR. For I959 Bryant and I deduced it as

$$
\frac{{ }^{90} \mathrm{Sr} / \mathrm{Ca} \text { infant bone }}{{ }^{90} \mathrm{Sr} / \mathrm{Ca} \text { cow's milk }}=\frac{4 \cdot 3}{9 \cdot 75} \simeq 0 \cdot 4 \text {. }
$$

Data for subsequent years give similar values; that is all are higher than the representative figure taken for adults $(0 \cdot 25)$. This observation could be the outcome of a net loss of $\mathrm{Sr}$ in the perinatal period (Widdowson, Slater, Harrison \& Sutton, r 960) and almost complete lack of discrimination in early infancy (Lough, Rivera \& Comar, ig63).

\section{The child}

In the subsequent few years the growth-rate declines (Fig. I). The additions of $\mathrm{Ca}$ according to Mitchell et al. (I945) are 47, 32, 22 and $\mathrm{I} 8 \mathrm{~g}$ in the next 4 years. Accreted salt is therefore a diminishing fraction of the accumulated total. It is important to know how much of the previously deposited material is turned over in the remodelling of growth. Kulp \& Schulert (1962) in the USA use for all ages a figure of $2 \cdot 5 \%$ /annum 'exchange' with diet. They produce excellent evidence for this value in adults, but to the physiologist it appears unreasonably low for growing children remodelling their bones.

The concept of 'exchange', which is not ion-exchange, is similar to what we have called 'replacement'. Purely for purposes of calculation one can consider a fraction of the skeleton with a given specific activity (sp. ac.) of $\chi \mathrm{pc}{ }^{90} \mathrm{Sr} / \mathrm{g}$ Ca replaced during I year with new salt of the sp. ac. of current diet $\mathrm{pc}^{90} \mathrm{Sr} / \mathrm{g} \mathrm{Ca} \times$ the appropriate OR bone/diet. In fact, of course, bone is resorbed and the osteogenous salts (sp. ac. - $\chi \mathrm{pc} / \mathrm{g}$ ) mix in the extracellular water and plasma with dietary salts (sp. ac.$\mathrm{y} \times \mathrm{OR} \mathrm{pc} / \mathrm{g})$. The new bone is formed from the mixture with specific activity intermediate between $\chi$ and y OR. Thus 'exchange' or 'replacement' is a considerable underestimate of 'turnover'. 


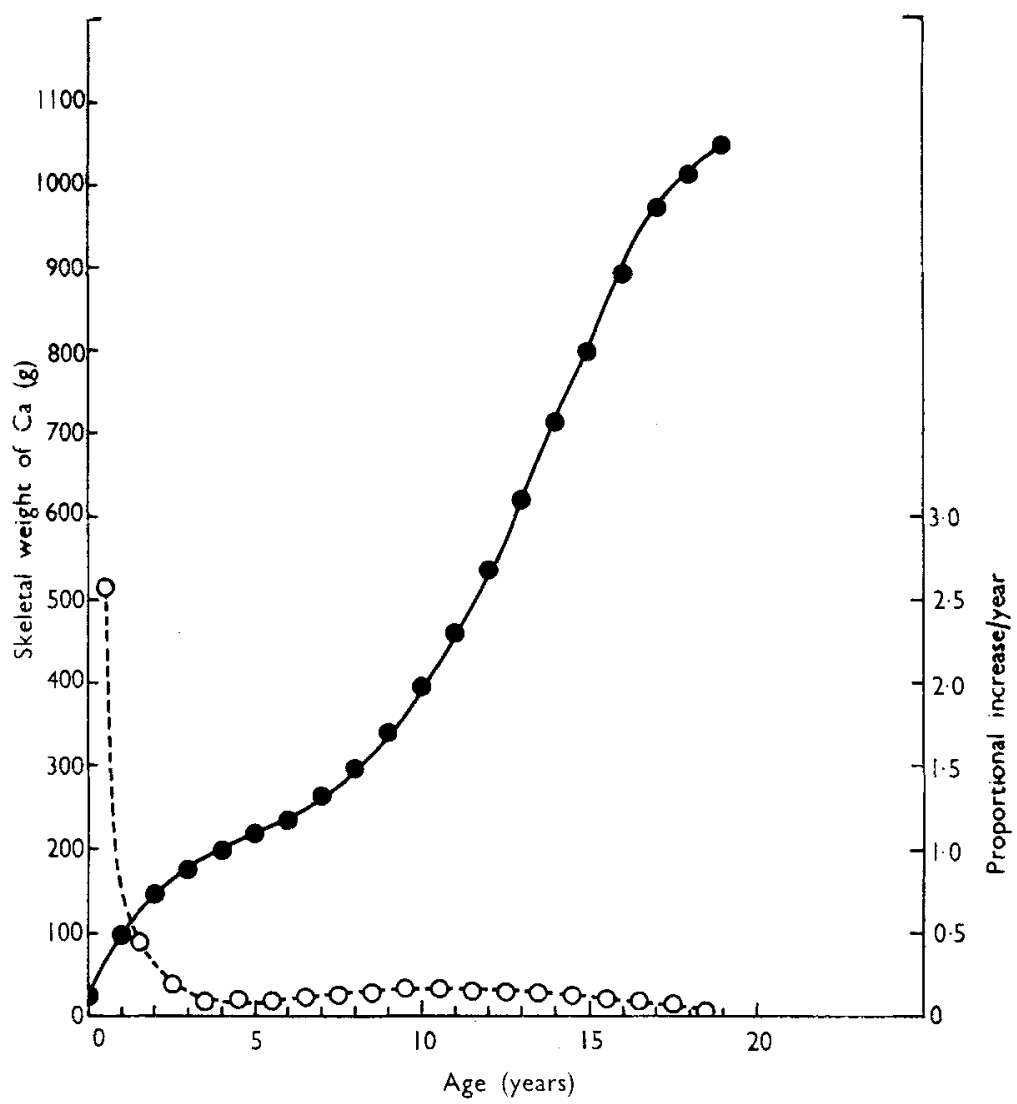

Fig. I. Mass of skeletal calcium (- $)$ and proportional increase/year $(0--0)$ according to child's age.

The calculation of Kulp \& Schulert (1962) involves a second constant-OR, and once again they use the value appropriate for adults, 0.25 . If, indeed the $O R$ is high in infancy, it probably progressively declines with age. Bryant and I, since we have data for stable $\mathrm{Sr}$ as well as ${ }^{90} \mathrm{Sr}$, prefer to consider the true specific activity pc ${ }^{90} \mathrm{Sr} / \mathrm{mg} \mathrm{Sr}$. This procedure abolishes the need to evaluate discrimination factors.

Let us therefore take as an example a model child of the 1957 cohort born in mid-year. Fig. 2 gives the best values we can deduce for specific activity and total ${ }^{90} \mathrm{~S} r$ in its skeleton, at the ages of $1,2,3,4$ in mid-1958, 1959, 1960 and 1961 .

Both values rise in the ist year, when the proportionate accretion of new bone is maximal. The 'national diet' and milk over this period contained $5^{-6} \mathrm{pc} / \mathrm{g} \mathrm{Ca}$, and if $0.5 \mathrm{mg} \mathrm{Sr} / \mathrm{g}$ Ca be assumed (see p. I4I) this gives a specific activity of diet of $\sim_{\mathrm{I}}$ $\mathrm{pc} / \mathrm{mg} \mathrm{Sr}$, i.e. rather higher than the value deduced for bone $(8 \cdot 6)$. In the 2 nd year, when diet was more contaminated (national diet-9.0 $\mathrm{pc} / \mathrm{g} \mathrm{Ca}$ (ARCRL 3 )) and diet of I-2 year olds deduced as $14 \mathrm{pc} / \mathrm{mg} \mathrm{Sr}$ (Bryant \& Loutit, I96I), and accretion of new bone reduced to $50 \%$ of the pre-existing skeleton, the specific activity of bone rose pari passu with diet to $12.6 \mathrm{pc} / \mathrm{mg}$ Sr. For the 3 rd year (diet deduced as $9 \mathrm{pc} / \mathrm{mg}$ $\mathrm{Sr}$ ) the specific activity of bone is recorded as $10.5 \mathrm{pc} / \mathrm{mg} \mathrm{Sr}$. Finally for the $4^{\text {th }}$ 


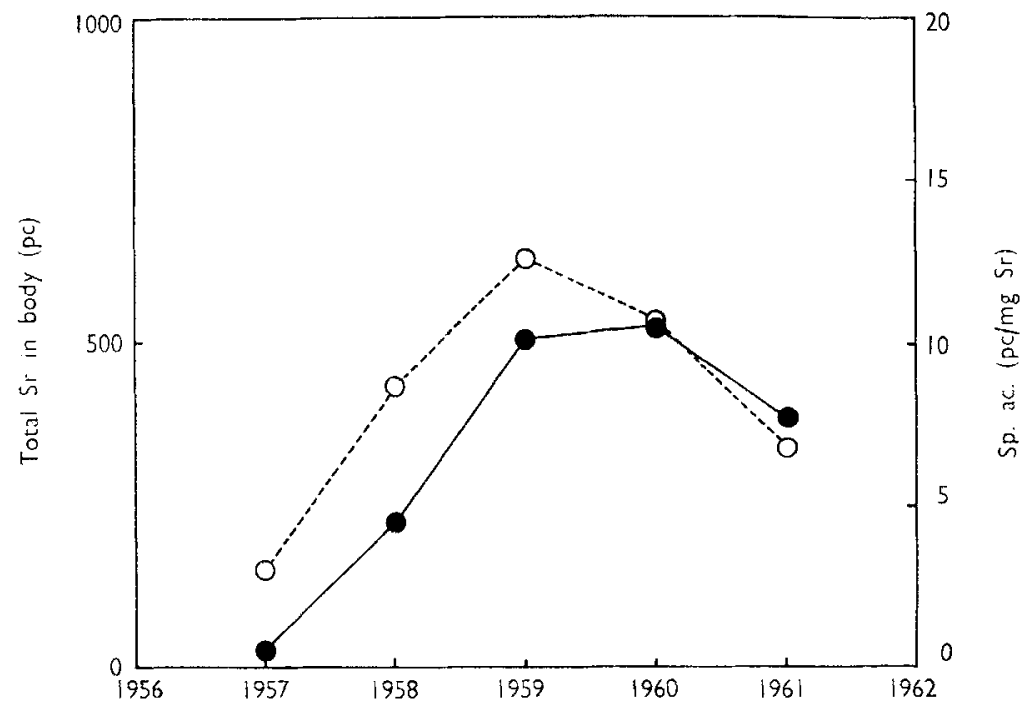

Fig. 2. Total ${ }^{90} \mathrm{Sr}$ in body (-O) and its specific activity (0-- - o) for a model child of the 1957 cohort in the years $1957-6 \mathrm{I}$.

year with diet deduced as $8 \mathrm{pc} / \mathrm{mg} \mathrm{Sr}$, the recorded value for bone is $6.8 \mathrm{pc} / \mathrm{mg} \mathrm{Sr}$. It is apparent that in these years, if we allow for errors, the specific activity of bone followed that of the contemporary diet very closely. In the last 2 years, moreover, accretion of new bone, $32 \mathrm{~g} \mathrm{Ca}$ and $22 \mathrm{~g} \mathrm{Ca}$, on pre-existing $147 \mathrm{~g} \mathrm{Ca}$ and $\mathrm{I} 77 \mathrm{~g}$ $\mathrm{Ca}$ was proportionately falling to 22 and $\mathrm{I} 2 \%$ respectively. Since accretion is a relatively small factor, the concordance of specific activities of diet and bone is indicative of a high rate of turnover.

The total ${ }^{90} \mathrm{Sr}$ in the skeleton, having risen in the first 2 years, owing to growth and a higher specific activity in diet in the 2 nd year, then levelled out and apparently was ultimately reduced. This is another way of visualizing that turnover is considerable in early childhood.

\section{The adolescent}

By contrast we can look at the data similarly obtained for a representative adolescent, of e.g. the 1947 cohort. Such a person in 1954 at the age of 7 would have had a skeleton of $264 \mathrm{~g}$ Ca virtually free of ${ }^{90} \mathrm{Sr}$. He would then enter the second burst of growth around the years of puberty. Fig. 3 shows a progressive rise in specific and total activity of the skeleton from 1956 to I96I. The data do not exclude some turnover, but one can conclude that they are largely accounted for by accretion of new bone with specific activities corresponding to the 'national diet' in these years (estimated as about $4 \mathrm{pc} / \mathrm{mg}$ Sr in 1956 and 1957 , and deduced from measurements as $4.5,6.9,4.9$ and 4.8 in the subsequent years). During this 5 -year period the skeletal $\mathrm{Ca}$ was approximately doubled, but the specific activity $\left({ }^{90} \mathrm{Sr} / \mathrm{mg} \mathrm{Sr}\right)$ at the end of the period was still well below that of diet. 


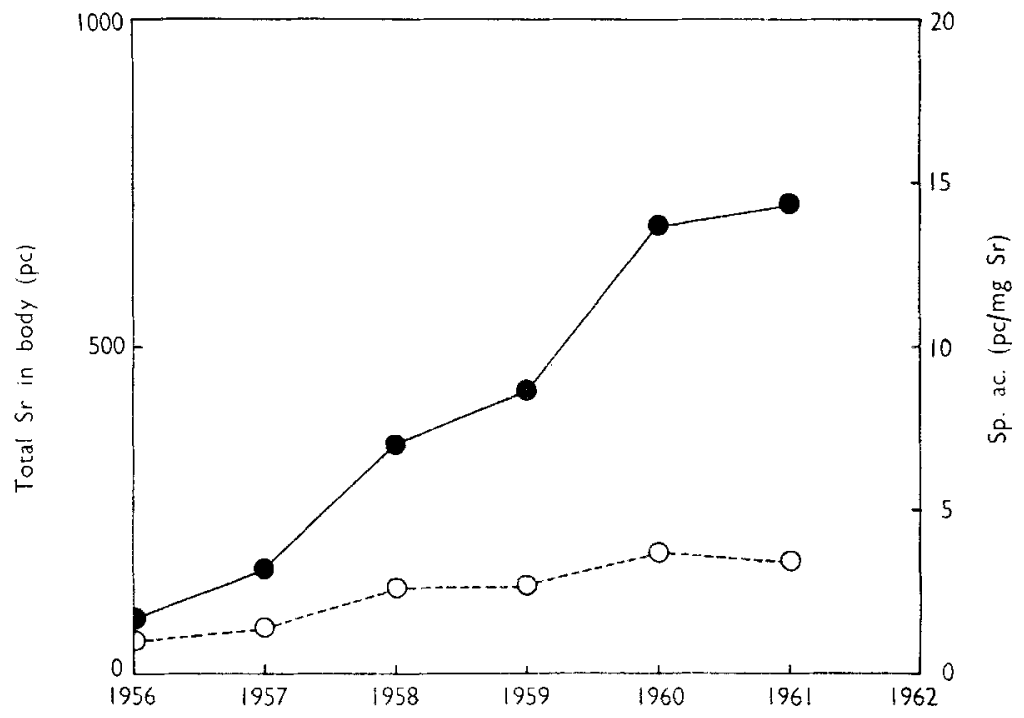

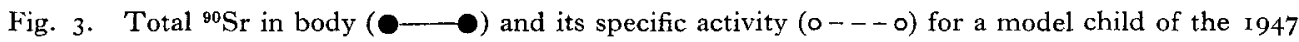
cohort in the years $195^{6-61}$.

\section{Summary}

I. Full-term infants in the UK are born with $\sim 28 \mathrm{~g}$ calcium and $\sim 5.6 \mathrm{mg}$ strontium in the skeleton. The ${ }^{90} \mathrm{Sr}: \mathrm{Ca}$ ratio varies according to the recent maternal diet, the contamination of which varies from year to year: its value is $\geqslant$ one-tenth of that of the maternal diet owing to discrimination between $\mathrm{Sr}$ and $\mathrm{Ca}$ by the mother in absorption, excretion and transplacental passage.

2. Maximal postnatal growth of the skeleton occurs in the Ist year of life. The discriminatory powers of such infants are less than those of adults.

3. In the subsequent few years observed values for $\mathrm{Sr},{ }^{90} \mathrm{Sr}$ and $\mathrm{Ca}$ suggest a very high rate of turnover of bone with a diminishing rate of accretion of new bone.

4. In adolescence similar data suggest that accumulation of ${ }^{90} \mathrm{Sr}$ is mainly due to accretion of new bone with diminishing turnover.

\section{REFERENCES}

Agricultural Research Council Radiobiological Laboratory (I958 to I96I-z). ARCRL I-8.

Bailey, N. T. J., Bryant, F. J. \& Loutit, J. F. (1960). Strontium-9o in Human Bone in the U.K. 19561958. Atomic Energy Research Establishment, Harwell, R-3299.

Bryant, F. J., Chamberlain, A. C., Spicer, G. S. \& Webb, M. S. W. (1958). Brit. med. F. i, I37I.

Bryant, F. J. \& Loutit, J. F. (I961). Human Bone Metabolism Deduced from Strontium Assays. Atomic Energy Research Establishment, Harwell. R-37i 8.

Comar, C. L., Wasserman, R. H. \& Nold, M. M. (1956). Proc. Soc. exp. Biol., N.Y., 92, 859.

Kulp, J. I. \& Schulert, A. R. (1962). Science, 136, 619.

Lough, S. A., Rivera, J. \& Comar, C. L. (1963). Proc. Soc. exp. Biol., N.Y., זr2, 631.

Mitchell, H. H., Hamilton, T. S., Steggerda, F. R. \& Bean, H. W. (1945). F. biol. Chem. 158, 625.

Newson, L. J. \& Newson, E. (1962). Brit. med. F. ii, 1744.

Rygh, O. (1949). Bull. Soc. Chim. biol., Paris, 31, 1052.

Widdowson, E. M. (I947). Spec. Rep. Ser. med. Res. Coun., Lond., no. 257.

Widdowson, E. M., Slater, J. E., Harrison, G. E. \& Sutton, A. (1960). Lancet, ii, 941. 